\title{
II. 関連領域の進歩と内科学・内科診療
}

\section{5. 医用工学}

Key words : 医用工学, バイオイメージング, フィジオーム,バイオメカニクス,バイオマテリアル, 人工㙎器

はじめに

医用工学 (medical engineering, $\mathrm{ME}$ ) は, 医 学・生物学と工学との境界領域の学問分野とし てこれまで発展してきた。初期のMEはmedical electronicsに代表されるように, 電子工学の医学 への応用が中心であったが, 時代の推移と共に 電子工学のみならず, 機械工学, 材料工学, 高 分子化学, 計測制御工学, 情報通信工学, 計算 機科学など幅広い領域の理工学が医学と医療の 発展に貢献してきた. 医用工学が医用生体工学 (medical and biological engineering ; MBE, biomedical engineering; BME) または医学・生物学 における工学 (engineering in medicine and biology ; EMB) とも言われる所以はここにある.

医用工学は, 心電図, 心臓ペースメーカ, CT (computed tomography) やMRI (magnetic resonance imaging)に代表されるように医学の進歩 を支えてきたし，また，医学の発展と共に医用 工学も進展し, 進化してきた.

医用工学は,このように, 医学と工学の要の 重要な学問であって, 単に, 医療機器の研究開

うえの しょうごう, あんどう じょうじ，いまち こう: 東京大学大学院医学系研究科医用生体工学講座
発にとどまらず，工学的な考え方や理論的思考 体系の提供により, 医学と生物学を統合的に把 握する学問体系を構築することを使命として発 展してきた. 国際的にも, 医用生体工学が“MBE integrates biology and medicine"として,ゲノ ムからポストゲノムへ移行する流れの中での考 え方の柱となっている. 各遺伝子の役割を機能 全体の中で見直すフィジオーム（physiome）の 考え方はその1例である.

医学と工学の融合としての医用工学の新しい 流れが医学・生物学を更に発展させるものと期 待される，それらは，例えば，バイオイメージ ング, フィジオーム, バイオメカニクス, バイ オマテリアル,バイオインフォマティクス,ニュー ラルエンジニアリング, ロボティクス, マイク ロ・ナノテクノロジー, 福祉工学など枚挙にい とまがない.

ここでは, バイオイメージング, フィジオー ム, バイオメカニクス, 人工臓器, 医用高分子 材料及びマイクロマシンについて概観する.

\section{1. バイオイメージング}

20 世紀の医学・医療は医用工学や放射線技術 の進展と共に急速に発展し、診断および治療の 
分野に計り知れない貢献をしてきた.ことに $\mathrm{CT}$, MRI, PET (positron emission tomography)，超 音波に代表されるバイオイメージングの開発は その中核的役割を果たしたともいえる。また， SQUID (superconducting quantum interference device）による心磁図MCG（magnetocardiogram) p脳磁図MEG (magnetoencephalogram) の生体磁気計測, 機能的MRI (functional MRI) による脳機能イメージング，経頭蓋的磁気刺激 TMS（transcranial magnetic stimulation）によ る脳賦活部位の可視化技術など，生体計測に新 しい手法が導入されてきた。

更には,エクオリンやGFP (green fluorescent protein）に代表される蛍光プローブの開発とそ れによる細胞内蛍光イメージングは，細胞内の 特定の遺伝子発現や細胞内シグナル伝達の挙動 を可視化することができるようになり，例えば， カルシウムイオンの細胞内取り込みやカルシウ ムウェーブの伝播の動的パターンを捕らえるこ とができるようになってきた.

しかし，癌をはじめとする多くの疾病におい てはそのメカニズムや治療効果の解明の点でさ らに高度のバイオイメージング技術の開発が望 まれている。我々は，これまでにない次世代の バイオイメージングを開発すると共にそれを利 用して, 癌, 放射線障害, 再生医療など細胞し ベルでのメカニズムや治療効果などを明らかに することを目的として，研究を推めている．そ れらは以下の通りである。

・リンパ節イメージング

・フリーラジカルのイメージング

・蛍光タンパク質イメージング

・心筋エネルギー代謝イメージング

・血管新生イメージング

・埋込型微小循環イメージング

・酸素分布イメージング

・高分解能でソフトな脳イメージング

・細胞内高分子ダイナミクスのイメージング

- X線顕微鏡
・放射線蛍光イメージング

これらバイオイメージング技術の進展により， 次の上うな研究が更に推進されるものと期待で きる。

・悪性腫瘍におけるリンパ節転移の研究

・放射線治療，放射線障害の研究

・心筋代謝イメージングによる心不全患者の 発症や進行・治療効果の研究

・内皮前駆細胞による血管新生の研究

-人工心臓の開発と人工循環に伴う全身循環 のイメージング研究

\section{2. フィジオーム}

最近，ヒトゲノムの解読が終了した。遺伝子 総数が約 3 万個，それがコードする蛋白質が約 25 万個存在すると考えられている.現在，ハイ・ スループットの質量分析計を用いた蛋白質の解 析（プロテオーム）がハイピッチで進められて いる.ささらに，そこから得られる膨大なデータ を高性能のコンピュータに集積して各種の処理 を行うバイオインフォーマティクスも同時に発 展してきている。これらの新しい技術が，数万 の遺伝子，数十万の蛋白質，何億もの細胞が相 互反応しながら機能することによって成立して いる生体に関する網羅的な情報を提供してくれ る。こうした状況のなか，生体機能システムを 統合的に解析しようとする新しいポストゲノム 研究が医用工学の領域で開始された. 1997 年に 米国NIHにBioengineering Consortium（生体工 学協会：BECON）が設立され，医学や生物学と 生体工学が融合して, 数学, 物理, 化学, 工学 を用いて遺伝子から生体の機能に至る過程を構 成的に理解して医学に役立てる研究の推進が謳 われ，そのための戦略が打ち出された。この中 で大きな柱となっているのが, フィジオーム (physiome) である.ここで“physio”はlifeや natureを, “ome”はas a whole entityを意味して おり，遺伝子情報や蛋白の機能解析を基に生体 
システムの機能を構成的（包括的）に理解しょ うとする研究を指す.フィジオーム研究の具体 的プロセスとしては，1）ゲノムゃプロテオーム のデータベースの作成と, 機能を主眼としたそ れらの系統的解析方法の開発(バイオインフォー マティクス)，2）生体システムを統合的に理解 するための計算機モデルおよびin vitroモデルの 作成（シミュレーション，モデル化），3）分子 から個体レベルにおける計測と実験(生体イメー ジング)，4）生体システムの機能原理の仮説の 提唱と検証, が含まれる.フィジオームは将来, コンピュー夕上に人間シミュレー夕 (in silico human）を実現するかもしれない.これは航空 機操縦の訓練のためのエアーフライト・シミュ レータのように，刺激を与えたときの生体反応 をシミュレートしてくれる。例えば, 運動の影 響について血圧や血流などの循環動態変化とと もに血管の組織や細胞で起こる分子・遺伝子レ ベルの反応に関する情報を得ることができるの である.これは医薬品の生体作用を実際の生体 を使わずにスクリーニングする手段としても有 用であろう。既に，コンピュータ上に細胞をモ デル化して, 環境の変化に対する細胞の応答を シミュレーションする技術（電子細胞；E-Cell） が登場している。

\section{3.バイオメカニクス}

生体の機械的現象を扱う生体力学（バイオメ カニクス）の研究が急速な進展を見せている. この分野では 1）人体の姿勢や歩行の調節および に各種スポーツにおける筋肉や骨格の動きのシ ミュレーションとモデリング，2）骨や靶帯の衝 撃に対する反応や有限要素法による応力分布の 計算，3）循環系の流体力学的解析と血流や血圧 に対する細胞応答の解析, 4) 心蔵弁, 血管, 骨 などの組織工学, に関する研究が活発に行われ ている。とくに内科とも関連する循環系のバイ オメカニクスでは心室内や大動脈の血流の特徴
が数值シミュレーションで明らかにされてきて おり,これらのデータは血流依存性に発生する 弜状動脈硬化症や大動脈瘤の発生機構の解明に 有用な情報を提供している，血流や血圧の変化 は心笳細胞，内皮細胞，平滑笳細胞などに流れ ずり応力や伸展張力といった力学的刺激（メ力 ニカルストレス）を与えている. 最近の研究で これらの細胞がメカニカルストレスに反応して 形態・機能を変化させる分子機構が明らかになっ てきた。メカニカルストレスにより細胞機能が 変化する際にはその機能に関連した遺伝子の発 現も変化することが多い。この遺伝子発現調節 は転写を介することが多く，メカニカルストレ スで活性化する転写因子と，それが結合する染 色体遺伝子上の特定のシス・エレメント（メカ ニカルストレス応答配列）が重要な役割を果た すことが判明した。また，DNAマイクロアレイ による解析でメカニカルストレスが数百を超え る遺伝子の発現に影響を及ぼすことが示された。 すなわち，メカニカルストレスに対する細胞応 答の背景には数十から数百の遺伝子がコードす る非常に多くの蛋白質の相互反応のネットワー クが存在しているのである。さらに細胞がメカ ニカルストレスを感知する機構の解明も進んで いる．これまでの研究でメカニカルストレスの 情報がイオンチャネル，細胞骨格あるいは接着 分子を通して細胞内へ伝達されることが分かっ ているが，現在，メカニカルストレスの特異的 センサー分子の探索が行われている．循環系の 細胞のメカニカルストレスに対する感知・応答 の分子機構が明らかになれば，循環系の働きの 恒常性の維持に果たす血行力学因子の意義が明 らかになるだけでなく渤状動脈硬化，動脈瘤， 高血圧といった血管病の病態の理解および新し い治療法の開発にもつながることが期待できる.

\section{4. 人工臓器}

人工臓器とは, 機能が低下したり, 不治に陥っ 
た生体蔵器の一時的あるいは半永久的な代替を 目標に開発された人工の組織や器官，骨格をい い, 循環系 (人工心臓, 人工血管, 人工弁, 人 工血液, 心臟ペースメーカ), 代謝系 (人工腎臓, 人工肝蔵, 人工朠臓), 呼吸器系 (人工肺, 人工 気管), 感覚系 (人工の視覚, 人工水晶体, 人工 角膜, 眼内レンズ, 人工の聴覚, 人工中耳, 人 工内耳, 人工触角), 骨格系 (人工骨, 人工骨頭, 人工関節, 人工腱, 人工歯根), 消化器系 (人工 腸管, 人工食道), 人工子宮, 人工皮膚など非常 に多種類のものが開発研究されており，その多 くは日常的に臨床に使われている，1996 年の 1 年間に我が国で使用された人工臟器は, 人工弁： 6,837 個, 人工血管 : 8,636 本, 心臟ペースメーカ : 13,601 台, 膜型人工肺 : 12,967 セット, IABP : 18,133 本, 補助心臓：30 例, 人工腎臓：116,724 人, 人工肝補助心臓 124 例, 人工荤島 : 1,481 例，人工骨 ·関節 : 18,759 例, 人工内耳 : 219 例，人工皮撔: 7,028 枚, 人工水晶体: 590,357 個など膨大な数に達している。ことに，人工血 管, 人工弁, 心臓ペースメーカ, 人工腎臓，で は 20 年以上の使用されている例も珍しくない. このように, 現在の治療医学は人工臟器なくし ては成り立たないといっても過言ではない段階 に来ている。

しかし一方では, 現在の人工蔵器にはまだ多 くの問題点も残されている。 その第一は，機能 が部分的にしか実現できていないことである。

例えば，現在の人工腎臓では老廃物や水・電解 質の処理しかできないが，生体の腎臓はそれ以 外に血圧の調整やホルモンの産生などの重要な 機能がある，二番目は，材料の生体適合性（抗 血栓性や組織適合性）や耐久性が不完全なこと である.このため, 小口径の人工血管はまだ臨 床応用が不可能で，人工弁や人工心臓など血液 と接触する人工臟器では抗凝固療法が必要であ る.三番目は, 小型・軽量化が不十分で, こと に実質臓器の人工臓器では体内に埋め込めるほ ど小型化が進んでいないなどである.けれども，
この分野は日進月歩の状態にあり，将来は臓器 移植を倰ぐことが期待されている．例えば人工 心臓では全てのシステムを体内に埋め込む段階 まで開発され，米国では臨床試験も開始されて いる.また，テレビカメラの画像を電気信号に 変換して脳に埋め込んだ多極の電極を通して視 覚野を刺激して画像を認識させる人工視覚は, ボランティアに埋め込まれ，車の運転が出来る ほどの諗識能力を示すなど, 今後ますますの発 展が期待されている.

\section{5. 医用高分子材料}

医用高分子材料とは，高分子材料の中でとく に医学，医療を対象に用いられるものをいう. 皮䖉, 粘膜, 組織, 血液などと接触するものの 他に高分子医薬品のように経口的に服用するも のもある。一般に，生体に適用される高分子材 料には，1）生体に害を与える成分を不純物とし て含まないこと，2）必要な機能を有し，必要な 期間その機能を維持できること，3）生体に対す る反応が少なく(生体適合性), 組織と接触する ものでは局所的な異物反応や全身的な毒性反応 やアレルギー反応を起こさず(組織適合性)，血 液と接触するものでは, 血液凝固, 血栓形成, カルシウム沈着, 溶血, 血漿タンパクの変性な どを起こさない（血液適合性）こと，4）とくに その目的で設計されたもの以外では生体内で溶 出, 劣化, 変性や分解などの反応を受けないこ と，5）消毒が可能なこと，6）原料や製品の品 質管理が十分にできることなどが要求される.

現在, 医用高分子としては, シリコーンゴム, ポリウレタン, ポリ塩化ビニル, ポリエチレン, ポリエステル, テフロン, ポリプロピレンなど 多くの材料が, ディスポ製品, 人工蔵器, 手術 用具, 補緅器具, 創傷被覆材, 接着剂, 医薬, 臨床検查機器などに用いられている。これらの 中でもとくに人工蔵器と補綴器具に関しては, 生体内で長期に使用される場合が多いためより 
㛜しい生体適合性が要求されるが，それらの条 件を完全に満足する高分子材料はまだなく，今 後の大きな研究課題となっている.

近年，高分子材料の分子設計技術が急速に進 歩しつつあり，医用高分子の分野でも材料の複 合化やインテリジェント化によって，バイオセ ンサや生体内薬液搬送システムDDS (drug delivery system), 生体内分解 - 吸収性高分子, 人 工筋肉など新しい応用研究も盛んに行われてい る.ことに生体組織工学や再生医療に打いては 細胞培養や組織形成の足場としての医用高分子 材料の重要性が注目されている.

\section{6. マイクロマシン}

ここでいうマイクロマシンとは, センサ，ア クチュエータおよびプロセッサの機能を有した 微小な機械をいう. 1980 年代の終わりに, 急速 な進歩を遂げた半導体加工技術によってシリコ ンを加工して直径数十〜数百ミタロンの歯車や 静電モー夕を製作することに米国で成功した。 これに端を発して今まで夢と考えられていたマ イクロメータオーダの微小な機械を作ろうとい
う試みが，米国，日本，ドイッなどで急速に高 まった. マイクロマシンという言葉は，その当 時日本で藤正らによって作られた和製英語であ る. マイクロマシンの定義はかなりフレキシブ ルであるが, 部品の細かさ, 全体の大きさ, 変 位の精細さなど様々な観点から定義づけられお り, 現時点ではセンチメートルオーダの機械や, 大きな機械本体に微小な動作をするアクチュエー タがついているものなどもこの範疇に入る，マ イクロマシンの開発研究としては, 微小機構, 微細加工, 微細組み立て, 微小潤滑 - 磨耗など の基礎研究の下に, 各種の微小アクチュエータ, センサ，材料などの開発が試みられている.

マイクロマシンの最も期待されている分野は 医学への応用である．終局的には，体内や血管 内を自由に動き回って, 各種の計測や診断, 手 術を含めた治療を行うロボットが考えられてい るが，これには生体適合性や駆動機構など現段 階では非常に困難な技術的な問題点があり，い つ頃できるかのメドはついていない。むしろ， 能動カテーテルによる血管内や腹腔内などの観 察や低侵襲の手術, 人工臟器や薬物搬送システ ムDDSなどへの応用に力が注がれている。 